\title{
PURA SIWA MANIK DALANG DI DESA PEMARON (PERSPEKTIF FILOSOFOFIS, FUNGSI DAN BUDAYA)
}

\author{
I Ketut Suardana \\ STKIP Agama Hindu Singaraja, Singaraja, Indonesia \\ Email: iketutsuardana@gmail.com
}

\begin{abstract}
ABSTRAK
Penelitian kualitatif ini memiliki manfaat teoritis dan praktis yang diulas mempergunakan Teori Religi, Teori Simbol dan Teori Fungsional Struktural. Dalam pengumpulan data, peneliti menggunakan beberapa metode, antara lain: metode observasi, metode wawancara, metode dokumentasi untuk mendokumentasikan kejadian yang ditunjang dari beberapa sumber pustka selanjutnya data dianalisis melalui langkahlangkah secara siklus yaitu mulai dari reduksi data, display/penyajian data, pengambilan kesimpulan.

Sejarah Pura Siwa Manik Dalang berawal dari perjalanan I Dewa Bagus Manik Dalang yang merupakan orang yang pertama kali mementaskan kesenian wayang kulit di Bali yang berasal dari Klungkung. Odalan di Pura Siwa Manik Dalang jatuh pada wuku Wayang yang dimulai pada hari Minggu Wuku Wayang sampai hari Sabtu Wuku Wayang. Struktur pembangunan tempat suci di Pura Siwa Manik Dalang di bagi menjadi dua bagian yaitu: Madya Mandala (Jaba Tengah), Utama Mandala (Jeroan).

Pangempon/panyungsung Pura Siwa Manik Dalang adalah krama pemaksan Desa Pakraman Pemaron dari warga Arya Lanang Dauh serta sebagian warga Pasek Gelgel yang ada di Dusun Munduk Piseng, Desa Anturan, Kecamatan Buleleng. Di lihat dari segi budaya hindu pura siwa manik dalang merupakan pura yang sangat perlu diletarikan karena pur tersebut dapat difungsikan sebagai pura pengobatan apabila ada orang yang lahir diantara wuku wayang sehingga perlu dib uatkan upacara penyapu leger.

Dengan keberadaan pura ini umat hindu yang berada diwilayah buleleng tidak perlu lagi memohon tirta pengelukatan wayang jauh-jauh cukup dengan memohon di pura tersebut pelaksanaan upacara sudah dianggap selesai.
\end{abstract}

\section{Kata Kunci: Filosofis, Religi, Budaya Hindu.}

\section{Pendahuluan}

Bali merupakan salah satu pulau kecil di antara beribu pulau yang ada di wilayah Negara Kesatuan Republik Indonesia. Walaupun luas wilayahnya sangat kecil tetapi Bali menyandang banyak nama karena keunikan dan keindahan alamnya serta budaya yang dimiliki, seperti Surga Dunia, Pulau Dewata dan Pulau Seribu Pura. Dari pernyataan tersebut pulau Bali sangat digemari dan dikagumi oleh banyak orang baik dari masyarakat lokal maupun manca negara yang melihat pulau Bali kaya akan budaya, alam, adat istiadat, kebiasaan masyarakat yang hidup di pulau Bali. Dan juga keberadaan pulau Bali tidak dapat terlepas dari masyarakat setempat yang mayoritas beragama Hindu.

Penganut agama Hindu di Bali pada khususnya sangat kental dengan budaya dan tata cara upacara yang dilakukan setiap hari, hal tersebut dilandasi oleh konsep ajaran agama Hindu itu sendiri yang disebut dengan Tri Kerangka 
agama Hindu yang meliputi tattwa, etika, dan upacara. Ketiga hal tersebut saling berkaitan satu dengan yang lainnya yang mutlak ada untuk mencirikan kehidupan beragama, dimana tattwa atau filsafat merupakan intisari dari ajaran agama itu sendiri, kemudian etika mengatur tentang tata cara tingkah laku baik dalam berbuat, berkata dan berpikir (Tri Kaya Parisudha) yang perlu disucikan agar setiap tindakan yang kita lakukan selalu terarah dan selalu dijalanNYA. Kemudian upacara yang merupakan upaya pencetusan rasa syukur, dan penyeimbang alam semesta beserta isinya yang menjadikan identitas dari agama Hindu di Bali.

Dari upacara terlahirlah konsep yadnya yang juga merupakan konsep dari ajaran agama Hindu. Ada 5 bagian yadnya yang disebut dengan Panca Yadnya yaitu dewa yadnya, pitra yadnya, rsi yadnya, manusia yadnya dan butha yadnya. Dewa Yadnya adalah yadnya atau persembahan suci yang ditujukan kepada Tuhan atau para dewa sebagai manifestasi dari Tuhan itu sendiri, Pitra Yadnya adalah persembahan suci yang ditujukan kepada leluhur ataupun arwah nenek moyang, Rsi Yadnya adalah persembahan atau penghormatan yang ditujukan kepada para maha Rsi, Manusa Yadnya adalah persembahan yang ditujukan kepada sesama manusia, dan Butha Yadnya adalah persembahan yang ditujukan kepada para butha kala. Yadnya yang dilakukan berdasarkan konsep diatas juga berkaitan dengan sarana prasara yang digunakan dalam yadnya itu sendiri, yadnya berupa materi, tenaga, maupun pikiran, tetapi yang terlihat jelas dan menonjol dalam kehidupan masyarakat Hindu di Bali adalah yadnya yang berkaitan dengan materi atau bebanten.Dari pelaksanaan yadnya ada tingkatannya yaitu nista, madya, utama yang menyesuaikan dari keadaan dan kondisi dari umat yang melaksanakan yadnya itu sendiri. Jadi ajaran agama Hindu sangat fleksibel terhadap umatnya.

Kemudian pelaksanaan yadnya itu sendiri sangat ditentukan oleh desa, kala, patra dari masing-masing daearah. Misalnya saja jika ditinjau dari segi waktu, sangat jelas bahwa pelaksaan yadnya tertentu memerlukan hari baik atau hari suci (padewasan), dan tinjauan dari segi tempat yadnya dapat dilakukan di berbagai tempat tergantung dari jenis yadnya yang dilakukan misalnya saja di pura, di pekarangan rumah, di perempatan, di kuburan, di sawah, di laut, di sungai, di gunung, di hutan, dll.

Agama bertitik tolak dari kepercayaan kepada Tuhan Yang Esa dalam ajaran Hindu dikenal dengan Panca Sradha. Pertama adalah Percaya akan adanya Tuhan, karena la yang berkuasa atas segala yang ada, Manusia pada dasarnya adalah makhluk religius, makhluk yang berTuhan, bahwa diluar batas kemampuan panca indria, dan di luar batas kemampuan akal pikiran manusia, ada suatu kekuatan luar biasa yang menciptakan, yang memelihara atau mengatur dan yang melebur atau mendaur ulang segala sesuatu yang ada di jagat raya ini.

Kedua Percaya akan adanya Atman atau Jiwatman. Atman adalah percikan kecil dari Tuhan. Bila atman meninggalkan badan, orang pun mati. Alatalat Tubuh pun hancur kembali kepada asalnya (Panca Mahabuta: Apah, Teja, Akasa, Bayu, Pertiwi). Atman yang menghidupi badan disebut jiwatman. Jiwatman dapat dipengaruhi oleh karma hasil perbuatan di dunia ini. Karena itu atman tidak akan selalu dapat kembali pada asalnya. Yaitu Parama Atman atau Tuhan. Menurut ajaran Agama Hindu Jiwatman orang yang meninggal itu dapat naik ke sorga atau turun ke neraka. Orang-orang yang berbuat buruk jatuh ke neraka. Di neraka Jiwatman itu mendapat siksaan, namun orang-orang suci yang tak terikat lagi pada ikatan dunia akan sampai ke dalam nirvana, alam kelepasan. 
Ketiga adalah Karmapala adalah hukum sebab akibat dalam suatu perbuatan. Karma berasal dari bahasa sansekerta yakni asal katanya $k r=$ membuat dan pala = hasil atau akibat. Melalui sistem penguraian dua kata tadi maka makna karmapala adalah akibat suatu perbuatan/hasil perbuatan. Contohnya apabila orang berbuat baik akan mendapatkan kebaikan. Begitu pula sebaliknya apabila orang berbuat jahat akan berakibat jahat juga. Hal ini yang menjadikan landasan dasar hukum Hindu sebagai hukum kodrat yang abadi dan tidak pernah diabaikan oleh masyarakat Hindu. Manusia dalam hidupnya tidak pernah luput daripada Subha asubha Praweri (karma) yakni: perbuatan baik dan buruk. Hukum kodrat karmapala terdiri dari tiga jenis yaitu: 1) Sancita Karmapala adalah hasil dari perbuatan kita dalam kehidupan terdahuu yang belum habis dinikmati dan masih merupakan benih yang menentukan kehidupan kita sekarang, 2) Prarabda Karmapala adalah hasil dari perbuatan kita pada kehidupan ini dan diterima habis pada saat hidup itu juga, dan 3) Kryamana Karamapala adalah hasil perbuatan yang tidak sempat dinikmati pada saat berbuat sehingga harus diterima pada kehidupan yang akan datang.

Keempatyaitu Punarbhawa Tatwa, merupakan keyakinan tentang mejelma kembali. Dalam bahasa sansekerta punar berarti lagi dan bhawa berarti menjelma. Dalam Weda disebutkan penjelmaan jiwatma berulang-ulang ke dunia ini disebut "Samsara". Kelahiran berulang-ulang ini membawa akibat suka-duka. Punarbhawa atau samsara ini terjadi karena jiwatma masih dipengaruhi oleh kenikmatan, dan kelahiran akan diikuti oleh kelahiran. Bahwa perbuatan manusia di dunia ini selalu menyebabkan danya berkas (wasana) dalam jiwatma. Bekasbekas perbuatan (karma wasana) ini ada bermacam-macam. Jika bekas itu hanya bekas-bekas keduniawian, maka jiwatma akan cenderung ditarik oleh duniawi, dan ia akan lahir kembali. Jadi setiap kelahiran adalah kesempatan manusia berbuat baik kepada semua ciptaan Tuhan tanpa kecuali untuk meningkatkan kesempurnaan hidup manusia. Disini nampak jelas konsep hukum karma phala memuat prinsip multikulturalisme karena mengajarkan manusia harus berbuat baik kepada siapapun dan perbuatan baik akan mendapat phahala yang baik juga.

Dan yang kelima Moksa adalah kelepasaan seseorang akan ikatan keduniawian, inilah tujuan akhir dari agama Hindu, orang yang telah mencapai moksa tidak akan terlahir lagi ke dunia, karena tidak ada apapun yang mengikatnya. la telah bersatu dengan parama atman (Sang Hyang Widhi). Bila air sungai telah menyatu dengan air laut, maka air sungai akan kehilangan identitanya. Tidak ada perbedaan lagi antara air sungai dengan air laut. Demikianlah juga halnya Atman yang mencapai Moksa telah menyatu dengan Brahman atau Tuhan. Pada saat itulah orang mengatakan " Aham Brahma Asmi ", artinya " Aku adalah Brahman".

Dari konsep Panca Sradha tersebut dimaksudkan bahwa umat dipermudah dalam menjalani segala aktivitasnya jika telah berpedoman dengan konsep-konsep diatas, dan berbagai kreativitas pun diwujudkan oleh umat untuk selalu dekat denganNYA. Salah satu diantaranya adalah dibangunnya tempat suci yang bertujuan memudahkan cara berhubungan umat dengan Tuhan.

Tempat suci keagamaan merupakan salah satu syarat dari terbentuknya suatu agama, yang mutlak dimiliki oleh suatu agama. Timbulnya tempat suci merupakan usaha manusia yang serba terbatas agar terciptanya suatu kehidupan yang damai dan sejahtera. Dalam buku "Agama Hindu Sebuah Pengantar" dikatakan: "Untuk memuja Tuhan Yang Maha Esa dalam berbagai aspek-NYA dibangunlah tempat-tempat pemujaan. Tempat itu adalah bangunan suci yang dibangun di tempat suci atau tempat yang disucikan. Tempat suci 
agama Hindu umumnya disebut pura, karena pura adalah tempat untuk memuja Tuhan dengan berbagai aspek-NYA maka pengertiaannya tidak dapat dipisahkan dengan konsepsi ketuhanan dalam agama Hindu itu sendiri. Menurut ajaran agama Hindu Tuhan itu Esa adanya. la yang Esa atau Tunggal itu ada dimanamana, tanpa batas dan tidak berwujud. Tuhan yang pada hakekatnya tanpa batas dan tanpa wujud itu kemudian diberi batas dan wujud dalam kepentingan pemujaan. la yang impersonal menjadi personal." (I Gede Sura, : 65)

Setiap umat beragama, baik agama apapun yang dianutnya tentu mempunyai tempat suci keagamaan. Timbulnya tempat suci merupakan usaha manusia yang serba terbatas agar terciptanya suatu kehidupan yang damai dan sejahtera. Dalam buku yang berjudul "Bagaimana Umat Hindu Menghayati Ida Sang Hyang Widhi" dikatakan : " cara yang paling mudah dan paling indah untuk mendekati Tuhan adalah melalui Rasa "untuk membangkitkan rasa agama, rasa cinta kepada Tuhan maka diperlukan suatu kondisi tertentu yang bisa menggiring agar rasa ketuhanan muncul dan menggelora dengan mantap. Dalam hubungan dengan hal ini, umat Hindu membangun tempat suci yang dinamakan Pura. (Cundamani, 1987 : 35).

Umat Hindu menyebutkan tempat sucinya secara umum adalah Pura yang digunakan sebagai tempat pemujaan. Dalam buku "Acara III" dikatakan : "Pura oleh umat Hindu adlah tempat suci untuk memuja lda sang Hyang Widhi Wasa dalam segala prabhawanya (manifestasinya) dan Atma Sidha Dewata". (Roh Suci leluhur)". (Wiana dkk, 1985 : 10).

Bali dijuluki dengan Thousand Temple, sebab hampir setiap jengkal tanahnya terbangun dengan tempat pemujaan. Tiap keluarga memiliki pura tersendiri, tiap desa ada tempat pemujaan, gedung-gedung, kantor-kantor dan tempat-tempat kegiatan selalu dilengkapi dengan bangunan pemujaan. Dalam masyarakat Hindu, tempat suci atau tempat pemujaan selain disebut pura, kahyangan, parahyangan disebut pula dengan sebutan-sebutan lain yang fungsinya hanya merupakan sthana sementara Ida Sang Hyang Widi Wasa. Dalam buku " Orang-orang Suci dan Tempat Suci disebutkan:

Bahwa tempat suci ini bukanlah merupakan tempat/sthana yang tetap dari Sang Hyang Widhi Wasa atau manifestasiNya, melainkan hanya merupakan tempat sementara, sebagai persimpangan. Ini berarti bahwa Tuhan dan manifestasiNya tidak menetap, tetapi hanya turun serta dilinggihkan (disthanakan) pada waktu tertentu apabila diperlukan, seperti: pasimpangan, pangayatan, pangubengan, penyawangan, pangayengan, palinggih dewa grha madira dan lain-lain. (Dibia, tt : 28-29).

Pura atau kahyangan itu dibangun disuatu tempat terpilih dan dibangun secara khusus serta menurut peraturan/ketentuan yang didasarkan pada hal-hal yang bersifat sekala atau niskala, sehingga pura atau kahyangan itu letaknya kadang-kadang sulit didatangi atau dicapai. Syarat membangun pura pun bukan merupakan sebuah perkara yang gampang mulai dari pemilihan tanah haruslah yang berbau harum, yang sebelumnya penentuan pembangunan pura telah ditentukan melalui musyawarah mufakat masyarakat setempat, kemudian dilanjutkan dengan ngeruak karang yaitu suatu upacara yang bertujuan untuk merubah status sebelumnya menjadi karang pura. Setelah itu dilaksanakan nyukat karang yakni mengukur karang areal pura yang akan dibangun sesuai dengan ketentuan sastra dan keyakinan umat Hindu, kemudian nasarin atau meletakkan dasar bangunan atau pondasi bangunan (pelinggih). Setelah bangunan rampung maka dilaksanakan upacara melaspas yaitu sebuah upacara penyucian terhadap bangunan yang akan didirikan, yang biasanya diiikuti dengan ngurip-urip yaitu menghidupkan secara simbolis bangunan yang sudah 
didirikan dan rangkaian upacara yang terakhir yaitu upacara Ngenteg Linggih yakni menentukan dan menetapkan piodalan bagi pura yang sudah didirikan dengan melaksanakan upacara penyucian sekaligus mendem pedagingan biasanya hari yang dipilih untuk melaksanakan upacara tersebut langsung diperingati sebagai hari piodalan yang dilaksanakan setiap enam bulan atau setahun sekali.

Pura juga merupakan simbol dari alam semesta atau makrokosmos. Setiap pura memiliki hari piodalan yang datangnya ditentukan sesuai dengan hari ngenteg linggih pura tersebut. Dalam piodalan pun menggunakan sarana-sarana salah satunya adalah banten piodalan yang disesuaikan dengan desa, kala, patra daerah setempat.

Keberadaan sebuah pura harus mampu menumbuhkan, mengobarkan emosi keagamaan umatnya yaitu berupa suatu getaran jiwa berupa rasa cinta: bakti dan kerinduan yang mendalam kepada Hyang Widhi sehingga mampu mendorong umat untuk berprilaku religius. Dari hal tersebut maka kepekaan umat pun mulai terkonsentrasi di bidang pemujaan, dengan di bangunnya banyak pura sebagai tempat persembahyangan maka pura dikelompokkan menjadi dua kelompok yaitu: 1). Berdasarkan fungsinya pura terbagi menjadi Pura jagat yaitu pura yang berfungsi sebagai tempat suci untuk memuja Hyang Widhi Wasa dalam segala prabawanya. Dan Pura keluarga yang berfungsi sebagai tempat suci untuk memuja Atma Sidha Dewata (Roh Suci Leluhur). 2). Berdasarkan karakteristiknya digolongkan menjadi empat bagian yang pertama Pura/Kahyangan Jagat yaitu pura yang berfungsi sebagai tempat suci untuk memuja Hyang Widhi Wasa dalam segala prabhawanya seperti pura Sad Kahyangan dan Pura Kahyangan Jagat lainnya. Kedua yakni Pura/Kahyangan Desa (Pura Teritorial) yaitu pura yang disungsung oleh desa adat atau desa pakraman. Ketiga yakni Pura Swagina (Pura Fungsional) yaitu pura yang penyiwiannya terikat oleh swaginanya (kekaryaannya) yang mempunyai profesi sama dalam sistem pencaharian hidup seperti Pura Subak, Pura Melanting, Pura Segara dan sejenisnya. Keempat adalah Pura Keluarga (Genealogis) yaitu pura penyiwiannya ditentukan olh ikatan Wit atau leluhur berdasarkan garis keturunan seperti sanggah/merajan, paibon, panti, dadia, batur, pedarman dan sejenisnya.

Dari sekian banyak jenis pura yang terdapat di Buleleng, ada sebuah pura yang bernama Pura Siwa manik Dalang yang letaknya di Desa Pemaron, dimana Pura ini disungsung oleh para krama pemaksan dan dibantu oleh para dalang yang ada di Kabupaten Buleleng khususnya, serta masyarakat Pemaron pada umumnya. Keunikan dari Pura Siwa Manik Dalang ini adalah setiap orang yang lahir pada wuku ringgit atau wuku wayang yang belum bisa mendatangkan wayang atau penyapuh legeran sebaiknya nunas tirta di Pura Siwa Manik Dalang sebagai penunda (petanggehan) pelaksanaan dari upacara tersebut yaitu dari umur 0-12 tahun.

\section{METODE}

Penelitian kualitatif ini memiliki manfaat teoritis dan praktis yang diulas mempergunakan Teori Religi, Teori Simbol dan Teori Fungsional Struktural. Dalam pengumpulan data, peneliti menggunakan beberapa metode, antara lain: metode observasi, metode wawancara, metode dokumentasi untuk mendokumentasikan kejadian yang ditunjang dari beberapa sumber pustka selanjutnya data dianalisis melalui langkah-langkah secara siklus yaitu mulai dari reduksi data, display/penyajian data, pengambilan kesimpulan. 


\section{HASIL DAN PEMBAHASAN}

\section{Sejarah Pura Siwa Manik Dalang di Desa Pakraman Pemaron}

Wayang dikenal semenjak Bali Kuna dalam pertunjukan pada abad 10, 11 atau 1000 tahun yang lalu sudah dikenal kesenian wayang di Bali. Di Bali wayang ini disebut bebali yang artinya adalah unsur tontonan dan bersifat sakral (suci). Selain bersifat hiburan dalam arti mendidik juga berarti suci. Segala kesucian ini dihimpun dan dihormati pada seperangkat alat wayang itu sendiri dan juga dihormati pada suatu tempat dibuatkan suatu pelinggih sebagai contoh Pura Siwa Manik Dalang yang berlokasi di Desa Pemaron. Segala sesuatu yang berkaitan dengan kesenian dan ada hubungannya dengan kesenian wayang maka di Pura inilah kesenian itu difokuskan. (Jero Dalang Ketut Winada, 13 Februari 2014)

Eksistensi Pura Siwa Manik Dalang di Desa Pakraman Pemaron sampai saat ini belum bisa diketemukan dalam lontar maupun prasasti, hal ini sangat menyulitkan untuk menelusuri keberadaannya, walaupun demikian informasi awal bisa diperoleh dari para tokoh agama dan para dalang secara turuntemurun yang nantinya bisa dibukukan walaupun dalam bentuk laporan hasil penelitian. Hal ini akan menambah keyakinan apabila bhakti masyarakat bisa diperkuat melalui informasi tertulis. Dari informasi yang didapat bahwa I Dewa Bagus Manik Dalang adalah orang yang pertama kali mementaskan kesenian wayang kulit di Bali yang berasal dari Klungkung. Beliau melakukan perjalanan dari Klungkung menuju Desa Gobleg Kecamatan Banjar untuk mencari keluarganya terlebih dahulu berada di Desa Gobleg. Orang tuanya menetap di Desa Gobleg sampai meninggal di sana, sedangkan I Dewa Bagus Manik Dalang melanjutkan perjalanan untuk mencari tempat tinggal yang lebih dekat ke pusat pemerintahan yaitu Buleleng. Dalam perjalanan beliau sampai tinggal di Dusun Munduk Piseng, Desa Anturan, tetapi tidak terlalu lama akhirnya beliau menuju Desa Pemaron. (Jero Dalang Nyoman Sadiana, 13 Februari 2014)

Tujuan beliau ke pemaron adalah ingin mencari tempat yang lebih representative antara Buleleng ke arah Timur dan arah Barat. Di Desa Pemaron ketika itu ada yang kesurupan (dirasuki) oleh penembahan atau sasuhunan yang disungsung oleh I Dewa Manik Dalang dan memerintahkan supaya beliau menetap dan bertempat tinggal selamanya di Desa Pemaron serta melaksanakan kewajiban sebagai dalang sampai pada keturunannya untuk selama-lamanya. Sejak itulah beliau terus menetap di Desa Pemaron dan tempat tinggal beliau dijadikan lokasi Pura Siwa Manik Dalang. (Jero Dalang Ketut Winada, 13 Februari 2014)

Sejak pemerintahan Raja Gendis abad ke XV, Pura Siwa Manik Dalang ditata dan dipugar kembali sampai pada jaman Raja Panji Sakti tahun 1584 dan tahun 1657 para dalang yang akan menyucikan diri atau mewinten dilaksanakan di Pura Siwa Manik Dalang, diyakini para dalang tersebut akan bertambah terkenal seperti dalang yang ada di Desa Tejakula, Patemon, Sukasada, Padangbulia, Penglatan, dan Banjar. 
Kewenangan-kewenangan yang menjadi pemangku di Pura Siwa Manik dalang adalah yang mendapat keturunan (totosan) dari pelingsir yang terdahulu.

Para dalang yang meyakini sebagai orang suci yang mampu menjadi penuntun dalam doa dan memohon air suci (tirtha pangeruwutan/panglukatan), tirtha sudhamala, sapuh leger dan juga menuntun dengan doa para atma yang dibuatkan upacara memukur atau ngaben dengan lakon cerita wayang "Bima Swarga" mendapat tempat yang baik sesuai dengan karma yang mereka perbuat. Tirtha yang dibuatkan oleh para dalang juga tidak bisa dipisahkan dari tirtha-tirtha lainnya seperti tirtha pendeta atau sulinggih, tirtha dari kemulan atau merajan, dari Pura Dalem atau tirtha dari Surya.

\section{Fungsi masing - masing pelinggih Pura Siwa Manik Dalang Desa Pekraman Pemaron.}

Pura Siwa Manik Dalang terdiri dari beberapa bangunan (pelinggih). Bangunan di bagian Utama Mandala (jeroan) di dalamnya dapat dijumpai 7 (tujuh) bangunan, yaitu: 1) Bangunan pertama yang paling besar adalah pelinggih Dewa Bagus Manik Dalang dan Dewa Ayu Manik Dalang, 2) Satu buah bangunan khusus Pelinggih Dewa Taksu Ngurah Semar, 3) Bangunan Pelinggih Surya, 4) Satu bangunan piasan para Dalang, 5) Satu buah bangunan piasan pesaren, 6) Satu bangunan tempat persembahyangan bersama, 7) Satu buah gedong penyimpenan.

Bangunan di bagian Madya Mandala (jaba tengah) dapat dijumpai 3 buah bangunan, yaitu: 1) Satu buah bangunan (jenis panggung), 2) Satu buah bangunan dapur (pewaregan), 3) Bangunan Pelinggih Jro Gede Ngurah Alit. Madya Mandala (jaba tengah) merupakan sebuah bangunan dapur (pewaregan) yang berfungsi sebagai tempat memasak / mengolah (mebat) untuk keperluan upacara pada waktu piodalan dilaksanakan. Tujuan dari prosesi masak di pura selain untuk kepeluan upacara odalan juga bertujuan untuk menjaga persatuan dan kesatuan bagi setiap umat Hindu pada umumnya dan bagi pengempon pura pada Khususnya. Masak bersama, sumbangan/peturunan dan makan bersama, secara tidak disadari akan menimbulkan jiwa sosial

Dari uraian di atas fungsi struktur pelinggih yang ada di Pura Siwa Manik Dalang adalah sebagai berikut:

\section{Pelinggih Dewa Bagus Manik Dalang dan Dewa Ayu Manik Dalang}

Fungsi dari pelinggih ini adalah nunas penganugrahan atau penglukatan ring Ida Bhatara Siwa yang lahir pada wuku ringgit atau wuku wayang. Untuk penglukatan petanggeh Kalau ada yang meminta penglukatan wayangnya yang melaksanakan penglukatan adalah mangku dalang. Sarana banten yang diaturkan pada pelinggih ini sekar idangan, pulegembal, suci sorohan pengulapan pengambeyan, prasista, rayunan 2 dulang, guru piduka, tetebasan 11 , jerimpen 2 , sate lilit ayam seayut, teterag, peras tataban, sagi sagi dan dilengkapi dengan sarana canang maupun sarana

2. Pelinggih Dewa Taksu Ngurah Semar

Fungsi dari pelinggih ini adalah untuk mengawasi segala tindak tanduk dalang dan krama pemaksan dan juga merupakan balancangan atau yang mengawasi/menjagapelinggih Siwa dan juga pelinggih ini berfungsi sebagai memberikan kelancaran di dalam melaksanakan kesenian wayang siapapun yang berkeinginan melaksanakan seni untuk memohon di Pelinggih ini. Sarana banten yang digunakan sorohan, sambutan lebeng matah, pajegan, sambutan di ngiyu, sambutan di wakul.

3. Pelinggih Jero Gede Ngurah Alit 
Fungsi dari pelinggih ini adalah penyapa tamu atau pecalang dari Pura Siwa manik Dalang. Sarana banten yang dihaturkan pada saat odalan adalah tipat gong dan segehan dihaturkan di bawah pelinggih.

4. Pelinggih Surya

Fungsi pelinggih surya adalah sebagai penerang sinar suci dalam artian jalan terang pada waktu upacara Yadnya melaksanakan odalan di Pura Siwa Manik Dalang.Sarana banten yang dihaturkan pada saat odalan adalah banten suci

5. Gedong Penyimpenan

Gedong Penyimpenan merupakan tempat penyimpenan alat sarana upacara, dimana due (milik alat dan sarana pura) disimpan. Tempat gedong penyimpenan ini berada di jeroan tepat disamping pelinggih Siwa. Fungsi gedong penyimpenan ini adalah untuk menjaga alat dan sarana upacara. Kita sebagai umat Hindu mempercayai dengan kesakralan - kesakralan benda suci yang dikeramtkan yang sudah memiliki kekuatan magis yang mengagumkan.

\section{Prosesi Upacara Piodalan}

Pelaksanaan upacara di Pura Siwa Manik Dalang pada saat odalan diadakan enam bulan sekali setiap wuku Wayang yang dimulai pada hari Minggu Wuku Wayang sampai hari Sabtu Wuku Wayang. Tetapi krama pemaksan sudah memulai kegiatan satu minggu sebelumnya yaitu mulai hari Minggu Wuku Ugu para krama sudah membuat bermacam-macam persiapan/perlengkapan, yaitu: untuk kaum laki-laki membuat bangunan sementara untuk tempat banten/sesajen, membuat kelatkat, penjor, katik sekar, dan lain - lain. Sedangkan kaum wanita mempersiapkan berbagai macam sesajen yang akan dihaturkan. Kegiatan tersebut belangsung selama satu hari menjelang odalan. Bagi krama yang tidak hadir pada saat kegiatan ngayah akan dikenakan sangsi atau denda sesuai dengan awig - awig yang berlaku sebesar 25.000 dan ada juga sangsi yang lainnya seperti disuruh membawa klangsah atau bambu. Tujuan absensi tersebut adalah untuk menghindari krama yang malas hadir, dan yang rajin tidak merasa kecewa dengan kerajinannya. Yang menjadi kelian (ketua) pengempon pura adalah Ketut Badra dan wakil kelian (wakil ketua) Putu Suweta.

Banten untuk keperluan odalan dikerjakan di bale atau piasan pesaren yang letaknya di utama mandala (jeroan). Bale pesaren ini fungsinya sebagai tempat metanding bagi para pesaren pura untuk membuat banten dan sesajen. Banten dominan dikerjakan oleh kaum wanita. Saran banten merupakan makna simbolis dari manifestasi Ida Sang Hyang Widhi Wasa yang diwujudkan dalam bentuk banten. (Jero Mangku Kompyang Siram, 1 Maret 2014)

Pada saat hari minggu banten sudah dilinggihkan di masing - masing pelinggih dan pada hari itu juga pukul 09.00 sampai pukul 10.00 melaksanakan pewayangan. Pewayangan dilaksanakan pada hari minggu sampai hari sabtu wuku wayang. Dan tepat pada hari Senin Wuku Wayang merupakan puncak piodalan atau hari pertama piodalan dimulai. Kalau odalan besar (ageng) dilaksanakan melis ke pantai (segara) pada waktu pagi harinya. Para dalang di Kabupaten Buleleng khususnya datang dan ikut mengadakan persembahyangan bersama dengan para krama pemaksan, masyarakat khususnya dan masyarakat Buleleng pada umumnya. Tidak hanya masyarakat Buleleng namun ada juga masyarakat dari luar daerah Buleleng, seperti dari Kabupaten Gianyar, Jembrana, Karangasem datang untuk meminta/nunas tirtha penglukatan khususnya yang mempunyai anak yang lahir pada Wuku Wayang. Selain itu masih juga ada tamu-tamu asing yang datang yang sekedar untuk melihat upacara piodalan tersebut. ( Jero Dalang Ketut Winada, 2 Maret 2014) 
Sarana banten atau sesajen yang digunakan setiap upacara piodalan besar maupun kecil di Pura Siwa Manik Dalang ini adalah :1) Tegteg Daksina, 2) Pule Gembal Sekar Setaman, 4) Pengulapan dan Pangambean, 5) Pajegan Pangiring, 6) Suci Sorohan, 7) Sekar Hidangan, 8) Tetebasan, 9) Jerimpen Sate, 10) Ketipat Gong, 11) Ajengan, 12) Sayut dan Sagi-sagi, 13) Betutu dan, 14) Bebek ( itik ) putih bila upacara piodalan besar

Prosesi nganteb dimulai pukul 20.00 wita. Setelah prosesi nganteb tersebut selesai, maka dilanjutkan dengan persembahyangan bersama. Dan kemudian setelah persembahyangan bersama selesai maka dilanjutkan dengan pertunjukan wayang kulit oleh para dalang yang bermaksud ingin mempertontonkan lakonnya. Bagi para dalang yang hadir dan bermaksud untuk melakukan pertunjukan wayang akan diatur secara bergantian oleh pengurus organisasi yang ada.

Pada saat nyineb tepat pada hari sabtu malam wayang sudah mulai dimainkan, pementasan wayang pada hari itu adalah wayang penyineban dan lanjutkan dengan menjalankan atau ngintarang bunga (sekar) yang dilakukan oleh pesaren di pura sampai putaran tiga kali. Setelah wayang selesai dimainkan barulah bunga (sekar) dipendem (dikubur) dengan banten pada tempat yang telah ada tepatnya di belakang pelinggih Siwa. (Jero Mangku Arka, 3 Maret 2014). Pura Siwa Manik Dalang yang dibangun di Desa Pemaron ada hubungan niskalanya dengan Desa Gobleg(Kecamatan Banjar ), yaitu ayahnya di Desa Gobleg dan putranya di Desa Pemaron.

Menurut keyakinan Umat Hindu Dharma umumnya yang mempunyai anak yang lahir pada Wuku Wayang biasanya dimintakan tirtha penglukatan ( air suci sebagai pengeruat/pembersihan terhadap anak tersebut). Karena kalau anak tersebut tidak dimintakan tirtha penglukatan, maka anak tersebut akan selalu merasa sakit, ngelamun pikirannya, kelihatan sifat-sifatnya seperti orang yang tidak waras, merasa ada orang mengejar-ngejar dirinya.

\section{Pangempon/ Penyungsung Pura Siwa Manik Dalang di Desa Pemaron}

Adapun pangempon/panyungsung Pura Siwa Manik Dalang adalah kramapemaksan Desa Pakraman Pemaron dari warga Arya Lanang Dauh serta sebagian warga Pasek Gelgel yang ada di Dusun Munduk Piseng, Desa Anturan, Kecamatan Buleleng. Disamping itu ada juga krama pangempon/panyungsung yang melalui ikatan kekeluargaan juang kajuang sehingga anaknya harus terjun makrama atau karena proses kapetengan/kesakitan atas kehendak beliau, setelah mereka sehat, maka mereka ikut makrama pangempon. Eksistensi Pura Siwa Manik Dalang tersebut sangat diyakini oleh umat Hindu khususnya di Desa Pakraman Pemaron sebagai tempat suci untuk memuja Ida Shang Hyang Widhi Wasa yang berfungsi sebagai dewanya para dalang yang disebut Dewa Bagus Manik Dalang karena semakin tahun semakin banyak anggota kramapangempon pura. Kewajiban semua anggota krama pangempon sama, disini tidak ada diskriminasi, semuanya statusnya sama yaitu wajib memelihara dan bertanggung jawab atas bangunan fisik, kesucian pura dan pelaksanaan upacara-upacara di pura.

Biaya upacara piodalan dibebankan kepada semua anggota krama pangempon pura secara bersama-sama, disamping dana punia dari para pamedek yang sembahyang saat pelaksanaan upacara. Pembagian tugas dan kewajiban dalam melaksanakan upacara merupakan tradisi yang telah diterima secara turun temurun sejak jaman dahulu. Antara hak dan kewajiban para pangempon pura dalam hal ini sangat jauh berbeda, dimana kewajiban lebih banyak dan lebih berat dibandingkan dengan hak yang harus diterima, tetapi 
karena keyakinan krama yang dilandasi sikap tulus dan ngayah, semuanya itu tidak menjadi permasalahan.

Hak dari pangempon pura adalah: 1) mendapatkan lungsuran banten setelah selesai upacara piodalan ataupun upacara yadnya lainnya, 2) mengajukan saran, usul dalam sangkepan, dan 3) berhak dipilih dan memilih menjadi prajuru organisasi pangempon pura.

Pamedek atau orang yang sembahyang di Pura Siwa Manik Dalang disamping krama pangempon juga para dalang yang berada diwilayah Kabupaten Buleleng dan juga di luar Kabupaten Buleleng yang menyebar di seluruh Bali yang mungkin karena kepentingan ekonomi, politik maupun kerohanian. Para pamedek tersebut umumnya secara rutin ikut berpartisipasi utamanya dalam setiap piodalan yang jatuh pada setiap Soma Kliwon Wuku Wayang (enam bulan sekali). Mereka melakukan persembahyangan sekaligus menghaturkan pertunjukan wayang dan dana punia sebagai wujud bhakti kehadapan sesuhunan disana. Para pamedek tidak terikat atas hak dan kewajiban terhadap keberadaan pura. Mereka hanya datang untuk sembahyang dan juga berdana punia secara ikhlas. Mereka tidak dibebankan biaya pemeliharaan dan pelaksanaan upacara. Pemangku di Pura Siwa Manik Dalang dipilih berdasarkan keturunan dan kesenangan Ida Bhatara. Adapun keturunan yang dipilih menjadi pemangku adalah keturunan dari warga Arya Lanang Dauh. Apabila Mangku lingsir seda (meninggal) digantikan oleh anaknya. Setelah melihat fenomena tersebut diadakanlah pembahasan dalam sangkepan krama sesuai dengan dresta yang berlaku di Pura Siwa Manik Dalang.

\section{SIMPULAN DAN SARAN}

Berdasarkan hasil penelitian yang diuraikan di depan secara mendetail untuk mendapatkan data yang memuaskan, maka dapat di tarik kesimpulan sebagai berikut: Pura Siwa Manik Dalang berdiri pada tahun 1804, fungsi pura ini, menurut keyakinan Umat Hindu Dharma umumnya yang mempunyai anak yang lahir pada Wuku Wayang biasanya dimintakan tirtha penglukatan (air suci sebagai pengeruat/pembersihan terhadap anak tersebut) di Pura Siwa Manik dalang. Karena kalau anak tersebut tidak dimintakan tirtha penglukatan, maka anak tersebut akan selalu merasa sakit, ngelamun pikirannya, kelihatan sifatsifatnya seperti orang yang tidak waras, merasa ada orang mengejar-ngejar dirinya. Pangempon/panyungsung Pura Siwa Manik Dalang adalah krama pemaksan Desa Pakraman Pemaron dari warga Arya Lanang Dauh serta sebagian warga Pasek Gelgel yang ada di Dusun Munduk Piseng, Desa Anturan, Kecamatan Buleleng. Disamping itu ada juga krama pangempon/panyungsung yang melalui ikatan kekeluargaan juang kajuang sehingga anaknya harus terjun makrama atau karena proses kapetengan/kesakitan atas kehendak beliau, setelah mereka sehat, maka mereka ikut makrama pangempon.

Struktur bangunan tempat suci di Pura Siwa Manik Dalang di bagi menjadi dua bagian yaitu: Madya Mandala (Jaba Tengah) pada Madya mandala adanya pelinggih Jro Gede Ngurah Alit, Bale pewayangan, dan dapur (pewaregan). Sedangkan di Utama Mandala (Jeroan) terdapaat pelinggih Dewa Bagus Manik Dalang dan Dewa Ayu Manik Dalang, Pelinggih Dewa Taksu Ngurah Semar, Pelinggih Surya, bangunan piasan para Dalang, bangunan piasan pesaren, bangunan tempat persembahyangan bersama, gedong penyimpenan. 


\section{DAFTAR PUSTAKA}

Acwin Dwijendra, Ngakan Ketut. 2012. Arsitektur Bangunan Suci Hindu, Denpasar : CV Bali Media Adhikarsa.

Arikunto, Ir.Suharsini, 1989. Prosedur Penelitian suatu Pendekatan Praktek, Bina Aksara, Jakarta.

Astrid Susanto, 1977 : 166-167. Metode Observasi Yaitu Observasi Sistematika dan Observasi Partisipasi

Glebet, Ir. Nyoman.1981/1982. Arsitektur Bali Kuno http://duniaentrepreneurs yukron.blogspot.com/2013/03/Validitas-Dan-ReliabilitasPenelitian.html http://id.wikipedia.org/wiki/teknik penguji keabsahan data

Koentjaraningrat, 1990. Antropologi Sosial Sosial. Bandung: CV. Bandung

Koentjaraningrat, 1997. Beberapa Pokok Antropologi Sosial. Jakarta: Dian Rakyat

Koentjaraningrat,1987.Sejarah Teori Antropologi, Jakarta: Universitas Indonesia (Ul-Press)

Marzuki,1977. Methodologi Riset, BPFE, Yogyakarta

Moleong, 1988: 12. Pencatatan Dokumen Penilaian Kualitatif

Netra, Drs. Ida Bagus, 1974. Methodologi Penelitian, FKIP UNUD, Singaraja

Pudja G,M.A.S.H. 1983. Tattwa Darsana, Jakarta : CV NUSA JAYA INDAH

Putram, 1993 : 21-94. Mengidentifikasi Informan Dengan Pendekatan Posisional Approach, Reputasinal Approach, Decimal Approach

Rata Ida Bagus, 1991. Desertasi Pura Besakih Sebagai Kahyangan Jagat

Suardana, Drs. I Ketut, 1993 Methodologi Penelitian, STKIP Agama Hindu Singaraja.

Sugiyono Prof.Dr. 2012.Metode Penelitian Kombinasi (Mixed Methods),Bandung: Alfabeta

Sura I Gede,Sindhu Ida Bagus, Dalem I Gusti,1994. Agama Hindu Sebuah Pengantar, Denpasar: CV Kayumas Agung

Sutisno Hadi, 1979. Teknik Penelitian, Ghelia, Bandung

Tim Penyusun,2003. Materi Penataran Pemangku dan Tukang Banten, Kabupaten Buleleng Singaraja

Titib, I Made, 1996. Teologi dan Simbol - Simbol Dalam Agama Hindu, Surabaya: Paramita 
Titib, Drs. M. 1989. Pengertian Pura dan Bangunan Suci di Bali, Denpasar: Yayasan Panti Asuhan Hindu dharma Jati.

Watra, Wayan,2007. Pengantar Filsafat Hindu (Tattwa I), Surabaya: Paramita

Wiana, I Ketut, 1992. Pelinggih di Pemerajan, Denpasar: Upada sastra.

Wiana Ketut, 1993. Bagaimana Umat Hindu Menghayati Tuhan, Jakarta: Pustaka Manik Geni

Wiananti Ni Putu,2009. Pura Keluarga dan Pratima, Denpasar: Pustaka Bali Post 